\title{
Potential use of Erica andevalensis and Erica australis in phytoremediation of sulphide mine environments: São Domingos, Portugal
}

\author{
M.M. Abreu ${ }^{\text {a,*}}$, M.T. Tavares ${ }^{\text {a }}$, M.J. Batista ${ }^{b}$ \\ ${ }^{a}$ Instituto Superior de Agronomia, Universidade Técnica de Lisboa (TULisbon), Tapada da Ajuda, 1349-017 Lisboa, Portugal \\ b INETI, Estrada da Portela, Zambujal, Apartado 7586, 2721-866 Alfragide, Portugal
}

Received 1 August 2006; accepted 20 April 2007

Available online 6 June 2007

\begin{abstract}
The area around the São Domingos copper mine (Iberian Pyrite Belt) is subject of great environmental concern as acid mine water occurs several kilometres downstream of the mine. In addition thousands of tons of mine waste are present. Erica australis and Erica andevalensis, which are two spontaneous plant species of this area, have been studied with regard to their potential for phytostabilization.

Soils and plants from São Domingos and from a reference site (Moreanes) were analysed for soil characteristics, chemical element content in soils (total and AB-DTPA bioavailable fraction) and in plants. Superficial and seepage water as well as waste material leachates were also analysed. Seepage water showed high redox potential (mean $481 \mathrm{mV}$ ), high conductivity (mean $4337 \mu \mathrm{S} \mathrm{cm}^{-1}$ ) and low $\mathrm{pH}$ values (mean 2.6), being classified as mining water. Leachate solutions possessed mainly high levels of $\mathrm{Fe}, \mathrm{Al}$ and $\mathrm{SO}_{4}^{2-}$. Soils in the mining area were highly contaminated in $\mathrm{Pb}, \mathrm{As}$ and $\mathrm{Sb}$. Locally also high values of $\mathrm{Cu}$ and $\mathrm{Zn}$ were encountered and the soil available fraction of the majority of the elements showed also quite high values.

E. andevalensis grows in soils with $\mathrm{pH}$ between 3 and 4, whereas E. australis was only found in soils with $\mathrm{pH}$ above 3.5. Both species grow spontaneously in soils, highly contaminated with $\mathrm{Pb}$, As and $\mathrm{Sb}$. These plants, even in the non contaminated soils, are Al-tolerant and Mn-accumulators. In contaminated soils these species are also As-tolerant.

Considering the tolerant behaviour in extreme environmental conditions, these Erica species may be of major importance for the recovery of the sulphide mining areas, with climate conditions compatible with its breeding and growing, by physical and chemical stabilization of contaminated soils and even waste materials.
\end{abstract}

(C) 2007 Elsevier B.V. All rights reserved.

Keywords: Phytostabilisation; acid mine drainage; sulphide mine waste; Erica andevalensis; Erica australis; Al and As tolerance; Portugal

\section{Introduction}

Mining activity was an important sector of the Portuguese economy during the 19 th and the first half of

\footnotetext{
* Corresponding author. Tel./fax: +351 213653432.

E-mail address: manuelaabreu@isa.utl.pt (M.M. Abreu).
}

the 20th centuries. The majority of the mining activity ceased due to the ore exhaustion, and the introduction of new and more profitable techniques elsewhere made the extraction unprofitable (Martins and Oliveira, 2000). Nowadays, only few mines are still active in Portugal.

São Domingos mine, south-east Portugal, is an abandoned copper mine situated in the Iberian Pyrite 
Belt. Exploitation has been known since the pre-roman times, and massive sulphides were exploited from 1868 until the exhaustion in 1966 (Custódio, 1996). Actually, the São Domingos area is subject of great environmental concern as acid mine drainage has acidified and contaminated sediments and soils along several kilometres of the water course (Quental et al., 2002).

The present condition of the São Domingos mining area suggests that phytoremediation should be considered one of the best solutions for recovering the soil characteristics and diminishing the risk for human health. The benefits of phytoremediation are quite obvious as it is non-expensive and non-disruptive to the landscape and to those living near the contaminated site (Rittmann, 2004; Adriano et al., 2004).

The phytostabilisation is a particular technology of the phytoremediation concept which could be the best strategy for the São Domingos mining area. The objective of phytostabilisation is not to remove metal contaminants from a site but rather to stabilise them and reduce the risk to human health and the environment. This is achieved using specific tolerant plants and can be improved by applying soil amendments in order to enhance the biogeochemical processes in soils that can contribute to immobilise trace elements (Adriano et al., 2004; Clemente et al., 2006). The presence of vegetation reduces water and wind erosion and may induce a soil hydraulic control, which can decrease the downward migration of contaminants into the groundwater. Furthermore, tolerant plants can help physical and chemical immobilisation of contaminants by root sorption or by inducing chemical retention in soil (Prasad and Freitas, 2003). Phytostabilisation has the advantage, over other phytoremediation techniques, to eliminate the need of treating harvested shoot residues as hazardous waste. Tolerant plant species used in phytostabilisation should not accumulate contaminants to parts of the plants (branches, leaves, fruits, seeds) that may be consumed by humans and animals (Prasad and Freitas, 2003).

In the São Domingos area several plant species have been recognized as tolerant to the mining environment (Veigas, 2005). Among these plants, two species of the genera Erica (Ericacea family) deserves special attention, Erica australis and Erica andevalensis. The latter species was described for the first time by Cabezudo and Rivera (1980). It grows on the banks of Tinto and Odiel rivers as well as on mining tailings in the same zone being its distribution limited, at the time, to the mining region of Andévalo (Spain). E. andevalensis was classified as an endangered species by the Andalusian (southern Spain) Regional Government, as its geographic distribution is limited to the pyrite mine environments (Aparício and
García-Martin, 1996). In Portugal, this species was identified in the São Domingos mine for the first time by Capelo et al. (1998), where it grows exclusively on soils developed on the sediments along the bank of the São Domingos river that carries acid water from the abandoned mine (Quental et al., 2002). E. australis, the other species of Ericaceae family that grows at São Domingos, is endemic in the Iberian Peninsula and NW Africa. It is widely distributed in various climates and soil types, but it can also grow on soils with high concentrations of trace elements, such as $\mathrm{As}, \mathrm{Cu}$ and $\mathrm{Pb}$ (Freitas et al., 2004).

The implantation of these plant species may be a valuable element for mining landscape restoration because of its compact growth as a shrub plant up to 1-2 $\mathrm{m}$ high, showing striking pink to crimson blossoms from June to December. In addition, E. andevalensis is the only angiosperm species adapted to extreme ecological conditions $(\mathrm{pH}<2.5$, strong impoverishment in nutrients, high heavy metals content) (Soldevilla et al., 1992) and it has never been observed, at our knowledge, growing out of Iberian Pyrite Belt mining habitats. However, it is likely that E. andevalensis species may become extinct as soon as its habitat changes, which illustrates the importance of the habitat in species conservation (Aparício and García-Martin, 1996).

Despite the interesting characteristics of these species, there are limited published studies dealing with its potential use for recovering pyrite mining environments. Soldevilla et al. (1992) and Asensi et al. (1999) studied the metal content of both Erica species and also its metaltolerant character, mainly for $\mathrm{Cu}$. The relationship between soil characteristics and $E$. andevalensis growing on soils from the Spanish Pyrite Belt has been studied by Buján et al. (2006), which concluded for the high plasticity of this plant to colonize sulphur mining soils with different biogeochemical characteristics. Despite E. australis was widespread in those mining environments most authors, except Soldevilla et al. (1992), did not present any data for this species. Other studies carried out by Garcia et al. (2005) and Garcia (2006) on both E. andevalensis and $E$. australis were focused on the antioxidant mechanisms for stress induced by soil trace metals contamination.

E. andevalensis belong to the Ericetum australiandevalensis plant community and, although it can grow as a monospecific population, it is frequently found in heathlands associated with other plants, such as E. australis and Cistus ladanifer in the Andévalo region (Spain) (Rivas-Martínez et al., 2001). In the São Domingos mining area, E. andevalensis has not been found growing side by side with E. australis, being however in some few places associated with Cistus monspeliensis, C. ladanifer and Juncus conglomeratus. 
The aim of this study was to evaluate the potential of $E$. andevalensis and E. australis for phytostabilisation of mining areas with acid mining generation, as the low substrate $\mathrm{pH}($ often $<4)$ of these environments usually inhibit or affect the growth of a great number of other plant species. In this context, it was evaluated, apart from biological parameters, the soil characteristics that justify the different spatial distribution of both Erica species in the São Domingos mining area.

\section{Site description}

São Domingos copper mine, located in SE Portugal (Fig. 1), is one of a number of volcanogenic massive sulphide deposits within the Iberian Pyrite Belt (IPB), which extends from Spain along the south region of Portugal, in Baixo Alentejo Province. The IPB hosted in Late Devonian to Middle Carboniferous ages a huge quantity of volcanic-hosted massive sulphide mineralization (1700 Mt of sulphides, totalling $14.6 \mathrm{Mt} \mathrm{Cu}$; 13.0 Mt Pb; 34.9 Mt Zn, 46,100 t Ag and $880 \mathrm{t} \mathrm{Au}$ ), distributed for more than 80 known deposits. The most important deposits in the Portuguese IPB include some not exploited (Lagoa Salgada), some presently exploited (Neves Corvo) or to be exploited again (Aljustrel), and some in an abandoned state (São Domingos, Chança, Lousal and Caveira, Cercal, Gavião, Montinho, Salgadinho) (Leistel et al., 1998).

The large area covered by the São Domingos mine, with more than $25 \mathrm{Mt}$ of ore extracted, is one of the most interesting abandoned mines in Portugal from the historical mining view point (Gaspar, 1998). The general geology of the mining area consists of the Volcano-Sedimentary Complex with acid and basic rocks from Tournaisian age (Webb, 1958). The area was described as being underlain by Palaeozoic sediments. In the northern mine area, Palaeozoic sediments consist of Gafo Formation with schists, silts, greywackes, acid and basic volcanism, and Represa Formation composed of schists, silts, greywackes and quartzwackes from the Upper Devonian age. In the south of the area occurs the Phylito-Quartzitic Formation of phyllites, silts, quartzites and quartzwackes and Barrranco do Homem Formation of phyllites, silts and greywackes of the same age (Oliveira and Silva, 1990). With the Hercynian compression the sedimentary assemblage was intensely folded and the more incompetent beds marked with a strong flow cleavage, dip at steep angles to the NNE.

Along the regional strike, sediments are intruded by dykes ranging from acid (porphyries) to basic (diabases) composing the Volcano-Sedimentary Complex of Lower Carboniferous age (Oliveira and Silva, 1990). To the south a large area covered by the Mértola Formation of Lower Carboniferous age consists of a turbiditic sequence of pelites and greywackes. The Volcano-Sedimentary Complex, orientated WNW-ESE, is represented by the alignment of the São Domingos and Pomarão anticline. In the flanks of this structure representative IPB rocks are exposed and marked by three volcanic acid episodes, separated by sedimentary episodes.

Associated with the mining works several facilities were developed, including a railway and harbour for ore transportation, two pyrite burning factories, water reservoirs, cementation tanks, network channels for acid water evaporation, and the mining village. These factories, one for copper concentration and another for sulphur extraction, were built in the beginning of the 20th century as a consequence of the lower $\mathrm{Cu}$ prices attained in the international market. Mine waste materials in the area were estimated as several hundred thousand tons. The open pit covers 6.2 ha and is $120 \mathrm{~m}$ deep; it is now partially filled with acid, brown to reddish coloured water (Custódio, 1996).

In the surrounding area of the open pit and downstream to Telheiro area (Fig. 1) were deposited different type of materials, such as metallurgical slags, sub-grade ore, pyrite ash, weathered host rock, and materials from gossan. The environmental problems associated with waste materials are still visible within an area around $30 \mathrm{~km}^{2}$. In the area between Achada do Gamo and the Chança river confluence (Fig. 1) the slopes of the stream valley, where acid mine drainage flows, are bleached due to ancient acid leaching by mine waters (Quental et al., 2002).

The climate, according to the Thornthwaite classification, is semiarid mesothermic with no excess water and small thermal efficiency in the hot season, and it can be divided in two distinct periods, a wet period from November to March and a dry period from May to September. The annual average air temperature is $17.6^{\circ} \mathrm{C}$, and annual precipitation is $559 \mathrm{~mm}$. Most of the area is covered by thin soils and natural rock outcrops are abundant.

\section{Materials and methods}

\subsection{Waste dump materials leachates}

Fourteen samples of waste dump materials were collected from the open pit to Achada do Gamo where the two pyrite burning factories were built (Fig. 1). After milling, $100 \mathrm{~g}$ of this material was shaken in $1 \mathrm{~L}$ of distilled water, for $24 \mathrm{~h}$, filtered with a $0.45 \mu \mathrm{m}$ filter and the solution leachate was analysed for several elements and for the anions $\mathrm{Cl}^{-}, \mathrm{SO}_{4}^{2-}, \mathrm{S}^{2-}, \mathrm{NO}_{2}^{-}, \mathrm{NO}_{3}$ by AAS and Ion Chromatography respectively. 


\subsection{Superficial and seepage water}

Conductivity, $\mathrm{pH}$ and Eh were measured in situ in superficial water (24 samples; Fig. 1), including open pit water and seepage water (12 samples; Fig. 1), using a field $\mathrm{pH}$ meter, a conductivity meter and a potentiometer. Seepage water that flows in the main river system draining the mining area, results from the underflow of the

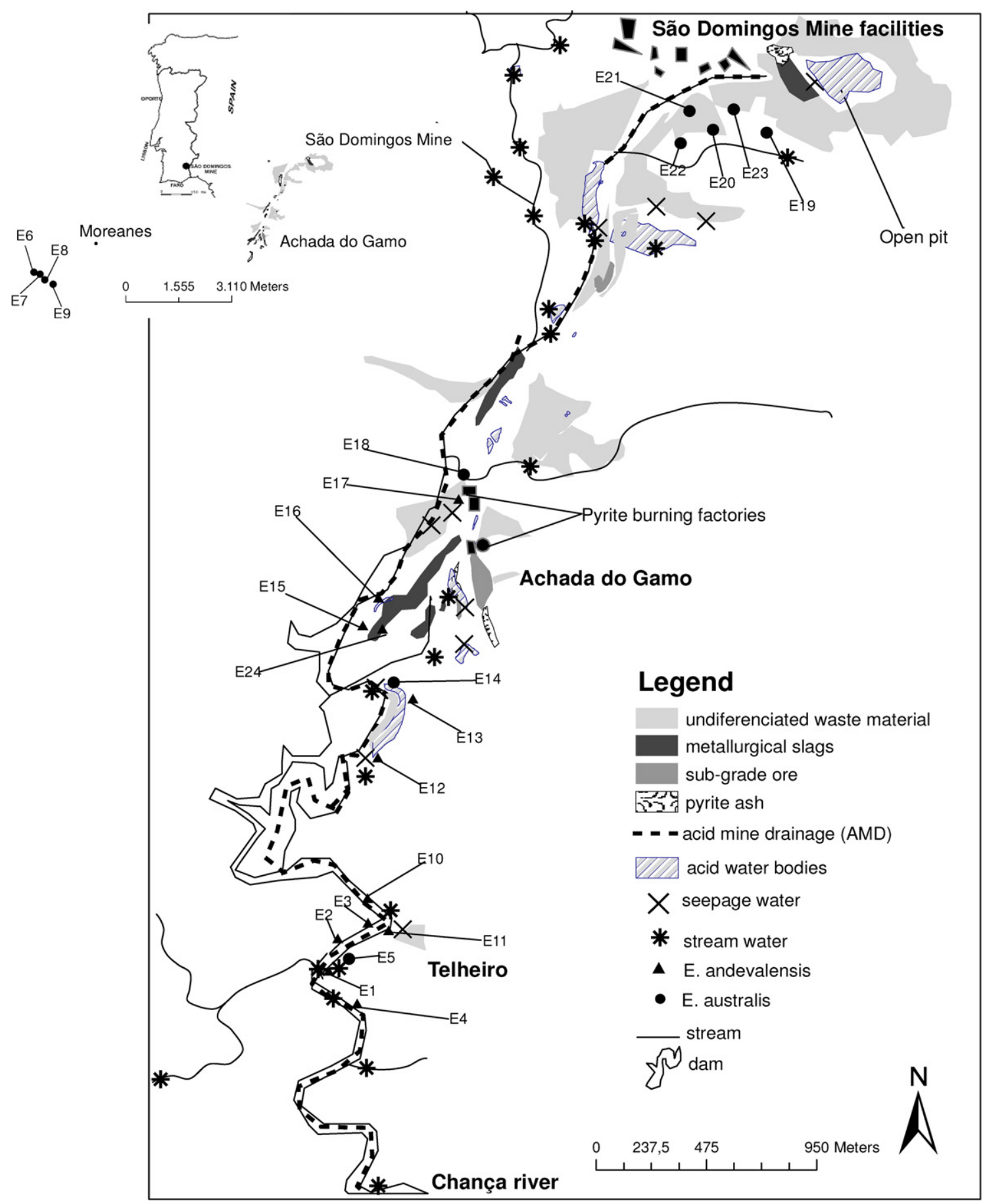

Fig. 1. Map of the São Domingos mining area with location of sample sites (soil, plant and water). 
infiltrated water in the waste materials, between consolidated bedrock and unconsolidated weathered material.

\subsection{Soils and plants}

Soil samples, developed on waste materials, weathered rocks mixed with waste materials with different composition and river bank sediments, were collected in the São Domingos mining area (20 samples; Fig. 1) and are representative, in the area, of the different soil environments where Erica plants grow. Aerial parts (stems, branches and flowers) of E. andevalensis and E. australis plants were also sampled in the same places; the roots were not included in the samples. Near the contaminated area, a non-contaminated site (Moreanes, Fig. 1) where E. australis grows was sampled for soils and plant composition reference (four samples).

Soils developed on coluvio-alluvial materials (river bank areas) were collected along São Domingos water stream (12 samples; Fig. 1) and E. andevalensis was sampled in the same areas as it corresponds to the spatial distribution of the plant. Soils from Moreanes were developed on schists and greywackes. Soils, where E. australis grows at São Domingos, were mainly developed on different waste materials (mostly of gossanous nature, but also slags and pyrite ash) and some on mixtures of weathered rocks, with a Moreanes similar lithology, and waste materials (eight samples; Fig. 1).

Soil samples were collected $(0-15 \mathrm{~cm}$ depth) in a restricted circle about $60 \mathrm{~cm}$ around the Erica plants and consisted of a homogeneous sample (around $4 \mathrm{~kg}$ ) of four subsample points. After sampling, the soils were dried at room temperature, mixed, homogenized and sieved through a $2 \mathrm{~mm}$ screen.

Soil samples (fraction $<2 \mathrm{~mm}$ ) were characterised as follows: $\mathrm{pH}$ in a water suspension (1:2.5 soil/water), organic carbon by Walkley-Black method (1934), and iron oxides (Mehra and Jackson, 1960). The same soil fraction $(<2 \mathrm{~mm})$ of each sample was analysed for total chemical content by ICP and INAA after four acid (HF $50 \%, \mathrm{HClO}_{4} 60 \%, \mathrm{HNO}_{3} 70 \%$ and $\mathrm{HCl} 37 \%$ ) digestion in Activation Laboratories Ltd. (Canada). Soil bioavailable fraction of the chemical elements was extracted with AB-DTPA (Hanlon et al., 1999) and analysed by AAS and ICP.

For plant samples, representative quantities of the aerial part of the plant (stems, branches and flowers) were collected in the same soil sampling places and, as soon as possible (within one or two days), were washed in abundant freshwater and rinsed with deionised water, dried at $30{ }^{\circ} \mathrm{C}$, homogenized and finely ground. Plants were analysed for total chemical content by ICP/MS also in Activation Laboratories, after ashing $\left(480{ }^{\circ} \mathrm{C}\right)$ and acid digestion.

\subsection{Data analysis}

Data analysis was carried out by univariate statistic using central tendency measures of the Gauss curve, such as mean and geometric mean, in the case of waste materials, median and dispersion measures, such as standard deviation and extreme measures (minimum and maximum values). Bivariate analyses were also performed using the relation between soil $\mathrm{pH}, \mathrm{AB}-\mathrm{DTPA}$ extractable fraction of $\mathrm{As}, \mathrm{Cu}, \mathrm{Mn}, \mathrm{Pb}, \mathrm{Sb}$ and $\mathrm{Zn}$, and the same elements in plants. Absorption coefficients (soil-plant coefficient transfer and bioconcentration coefficient; adapted after Nagaraju and Karimulla, 2002; Anawar et al., 2006) were estimated from the soil-plant relationship. The soil-plant coefficient transfer (TC) evaluates the transference of an element from soil to plant and represents the capacity of a species to accumulate the element $(\mathrm{TC}=[$ plant element $] /[$ total soil element]). Most plants have a $\mathrm{TC}<1$ for trace elements (heavy metals and metalloids). However, there are some few plant species that can be considered accumulators when TC $>1$. This coefficient can also be an indirect indicator of the soil bioavailable fraction of the element. The bioconcentration coefficient (BC) reflects the plant capacity to absorb the element from the soil when it occurs in an available form (water soluble or water soluble plus exchangeable) determined after soil chemical extraction using an appropriated solution $(\mathrm{BC}=$ [plant element $] /[$ element bioavailable soil fraction, extracted by AB-DTPA]). Therefore, when trace elements are considered, and in lack of phytotoxicity signs, $\mathrm{BC}$ represents the level of plant tolerance for a potential toxic element, the plant being tolerant when $\mathrm{BC}>1$.

\section{Results and discussion}

\subsection{Waste dump leachates, seepage and superficial water}

Table 1 shows the results of $\mathrm{Al}, \mathrm{Fe}, \mathrm{Pb}, \mathrm{Cu}, \mathrm{As}, \mathrm{Zn}$ and $\mathrm{SO}_{4}^{2-}$ concentrations in the waste leachates. All leachate solutions presented very high concentrations of $\mathrm{Fe}$ (median $3.4 \mathrm{~g} \mathrm{~L}^{-1}$ ), sulphur (median $7 \mathrm{~g} \mathrm{~L}^{-1}$ ) and $\mathrm{Al}$ (median $0.97 \mathrm{~g} \mathrm{~L}^{-1}$ ) and relatively low concentrations of all other determined elements. However, water leachates from gossanous materials and metallurgic slags showed high $\mathrm{Pb}$ and high $\mathrm{Zn}$ and $\mathrm{Cu}$ concentrations, respectively. The high $\mathrm{Pb}$ found in gossanous 
material is considered a relative $\mathrm{Pb}$ increase as the result of ore weathering processes, while other elements are easily remobilised from the ore materials. The $\mathrm{Zn}$ concentration in the metallurgical slags is expected as the element exists in the mineralization but was not recovered in the treatment process. The $\mathrm{Cu}$ concentration can also be justified by the inefficient metallurgical treatment of $\mathrm{Cu}$ extraction process.

Seepage water that flows into the São Domingos stream, in Achada do Gamo and São Domingos sites (Fig. 1) showed the lowest values of $\mathrm{pH}$ (mean 2.6), and the highest values of Eh and conductivity, respectively, (mean $481 \mathrm{mV}$ ) and (mean $4337 \mu \mathrm{S} \mathrm{cm}{ }^{-1}$ ). The main stream, beginning at São Domingos mine buildings and extending to the Chança river confluence (Fig. 1), constitutes the acid mine drainage (AMD) as indicated by low $\mathrm{pH}$ and high Eh (Fig. 2) and conductivity, ranging from $162 \mu \mathrm{S} \mathrm{cm}^{-1}$ to $19999 \mu \mathrm{S} \mathrm{cm}^{-1}$ (median value $580 \mu \mathrm{S} \mathrm{cm}^{-1}$ ). This acidic water shows a dark red colour due to high concentrations of Fe. The low $\mathrm{pH}-$ high Eh range lies in the mine water stability field for the oxidised water (mining water) according to Garrels and Christ (1965) $\mathrm{pH}-\mathrm{Eh}$ diagram and represents the seepage and São Domingos stream water (Fig. 2).

By contrast, the superficial water outside the direct influence of the mining area presented low Eh and conductivity values and high $\mathrm{pH}$. The stability of these water samples shown in the $\mathrm{pH}-$ Eh diagram (Fig. 2) is within the transition zone.

\subsection{Soils and plants}

Soil characteristics $(\mathrm{pH}$, organic carbon and iron oxides) are presented in Table 2. Comparing both contaminated and non-contaminated (Moreanes reference site) soils, the organic carbon content was similar, being low to very low, in agreement with the climatic conditions of the region. In the contaminated soils, iron oxides presented the highest values, and the $\mathrm{pH}$ ranged between 3 and 4.5, while in the reference soils $\mathrm{pH}$ was above 4.6. The enrichment of São Domingos soils on

Table 1

Statistics of concentrations of $\mathrm{Al}, \mathrm{Fe}, \mathrm{Pb}, \mathrm{Zn}, \mathrm{Cu}, \mathrm{As}$ and $\mathrm{SO}_{4}^{2-}$ measured in leachates of 14 samples of mining waste $\left(\mathrm{g} \mathrm{L}^{-1}\right)$

\begin{tabular}{llllrlrl}
\hline Statistics & $\mathrm{Al}$ & $\mathrm{Fe}$ & $\mathrm{Pb}$ & $\mathrm{Zn}$ & $\mathrm{Cu}$ & $\mathrm{SO}_{4}^{2-}$ & $\mathrm{As}$ \\
\hline Mean & 1.48 & 4.21 & 0.0300 & 2448.07 & 0.100 & 7.70 & 0.0062 \\
Median & 0.97 & 3.45 & 0.0070 & 50.00 & 0.016 & 7.10 & 0.0009 \\
Geom. Mean & 0.80 & 3.99 & 0.0095 & 173.45 & 0.022 & 7.50 & 0.0019 \\
Minimum & 0.05 & 2.95 & 0.0012 & 20.00 & 0.002 & 5.60 & 0.0003 \\
Maximum & 3.94 & 7.02 & 0.1400 & 15052.00 & 1.100 & 11.60 & 0.0298 \\
\hline
\end{tabular}

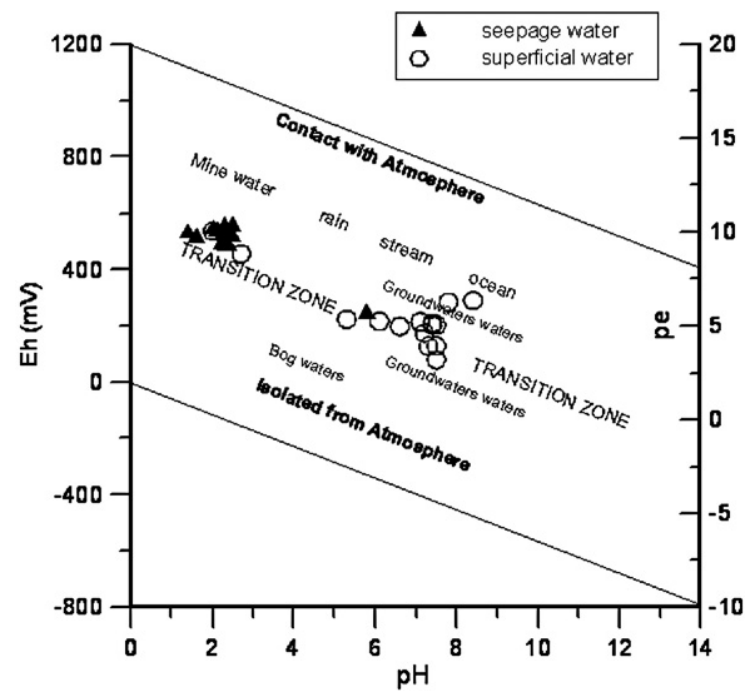

Fig. 2. Representation, in the diagram of stability limits for natural waters at the Earth surface, of the São Domingos waters (seepage and superficial), in terms of Eh and $\mathrm{pH}$ at $25^{\circ} \mathrm{C}$, after Garrels and Christ (1965).

iron oxides is related to acid weathering of solid phases and to mining water characteristics (Fig. 2).

The organic carbon and the iron oxides concentrations were also similar for both contaminated soils (Table 2), but E. australis soils presented the minimum values of iron oxides lower than those of $E$. andevalensis. This is a consequence of the Fe concentration in the AMD, which enriched soils where $E$. andevalensis grows. The $\mathrm{pH}$ values were considerably lower in the $E$. andevalensis soils due to its location near the AMD. In the São Domingos area, E. australis was not found in soils with $\mathrm{pH}$ values below 3.5 , while $E$. andevalensis grows in soils with $\mathrm{pH}$ between 3 and 4 (Table 2). A study in vitro carried out by Garcia et al. (2005) showed that $E$. andevalensis does not need acid soils to survive, but its prevalence in such hostile environments should be due to mechanisms which allow a competitive advantage in extreme conditions. This mechanism seems to be related to the synthesis or activation of enzymes with peroxidase activity (Garcia, 2006).

Buján et al. (2006) found E. andevalensis plants growing in soils (Andalusia, Spanish IPB) with $\mathrm{pH}$ values between 3.3 and 6.2, which do not agree with the results obtained for São Domingos soils (Table 2). The $\mathrm{pH}$ differences observed between the two sites (Spain and Portugal) may be related to biological characteristics of $E$. andevalensis growing in the different mining areas. At São Domingos E. andevalensis may correspond to a different plant phenotype not adapted to soil $\mathrm{pH}$ values higher than 4 , and probably related to recent colonization of mining sulphide sites in Portugal. In 
Table 2

Descriptive statistics of soil chemical properties ( $\mathrm{pH}, \mathrm{Fe}$ oxides - Fe ox and organic carbon - OC) and elements concentrations of AB-DTPA extractable fraction of soil samples collected in three areas with Erica growth

\begin{tabular}{|c|c|c|c|c|c|c|c|c|c|c|c|}
\hline \multirow[t]{2}{*}{ Statistics } & \multirow[t]{2}{*}{$\mathrm{pH}$} & \multirow[t]{2}{*}{ Fe ox } & \multirow[t]{2}{*}{$\mathrm{OC}$} & \multicolumn{8}{|c|}{ AB-DTPA extractable fraction } \\
\hline & & & & $\mathrm{Fe}$ & $\mathrm{Mn}$ & $\mathrm{Al}$ & $\mathrm{Cu}$ & $\mathrm{Zn}$ & $\mathrm{Pb}$ & As & $\mathrm{Sb}$ \\
\hline \multicolumn{12}{|c|}{ E. australis - non contaminated soil $(n=4)$} \\
\hline Mean & 4.8 & 10.04 & 32.91 & 305.8 & 55.42 & 45.83 & $<\mathrm{dl}$ & 5.00 & 12.57 & $<\mathrm{dl}$ & 0.36 \\
\hline Min. & 4.6 & 6.82 & 12.71 & 106.7 & 14.67 & 6.67 & $<\mathrm{dl}$ & 1.00 & 1.60 & $<\mathrm{dl}$ & 0.14 \\
\hline Max. & 5.0 & 12.00 & 55.73 & 480.0 & 122.67 & 86.67 & $<\mathrm{dl}$ & 8.67 & 30.00 & $<\mathrm{dl}$ & 0.84 \\
\hline Median & 4.8 & 10.67 & 31.60 & 318.3 & 42.17 & 45.00 & $<\mathrm{dl}$ & 5.17 & 9.33 & $<\mathrm{dl}$ & 0.23 \\
\hline Stand. Dev. & 0.2 & 2.38 & 18.88 & 184.0 & 48.81 & 32.93 & $<\mathrm{dl}$ & 4.06 & 13.57 & $<\mathrm{dl}$ & 0.33 \\
\hline \multicolumn{12}{|c|}{ E.australis - contaminated soil $(n=8)$} \\
\hline Mean & 4.0 & 29.25 & 27.13 & 211.3 & 35.79 & 55.83 & 34.04 & 6.33 & 79.6 & 5.08 & 0.59 \\
\hline Min. & 3.5 & 4.78 & 3.41 & 66.7 & 1.67 & 10.00 & 1.33 & 1.33 & 1.67 & 0.67 & 0.28 \\
\hline Max. & 4.5 & 56.95 & 137.40 & 600.0 & 144.33 & 126.67 & 102.00 & 13.33 & 223.3 & 20.00 & 0.91 \\
\hline Median & 4.0 & 28.56 & 8.30 & 156.7 & 3.50 & 35.00 & 22.83 & 5.83 & 28.17 & 1.33 & 0.58 \\
\hline Stand. Dev. & 0.3 & 18.09 & 45.35 & 175.3 & 53.31 & 49.11 & 34.60 & 4.05 & 95.72 & 7.21 & 0.23 \\
\hline \multicolumn{12}{|c|}{ E.andevalensis - contaminated soil $(n=12)$} \\
\hline Mean & 3.5 & 34.39 & 11.08 & 460.3 & 30.47 & 30.00 & 39.03 & 29.17 & 236.7 & 32.31 & 0.97 \\
\hline Min. & 3.0 & 18.49 & 2.95 & 110.0 & 2. 67 & 3.33 & 2.67 & 2.00 & 3.00 & 1.00 & 0.28 \\
\hline Max. & 4.1 & 58.49 & 32.14 & 790.0 & 109.00 & 80.00 & 137.67 & 83.33 & 1163.3 & 165.7 & 2.92 \\
\hline Median & 3.5 & 30.89 & 9.08 & 483.3 & 17.50 & 20.00 & 20.00 & 16.00 & 41.67 & 5.83 & 0.79 \\
\hline Stand. Dev. & 0.3 & 13.39 & 8.58 & 242.8 & 35.47 & 25.23 & 38.88 & 27.83 & 408.6 & 58.48 & 0.70 \\
\hline
\end{tabular}

dl: detection limit.

(Fe ox and OC in $\mathrm{g} \mathrm{kg}^{-1}$, AB-DTPA extractable fraction in $\mathrm{mg} \mathrm{kg}^{-1}, \mathrm{Hg}<\mathrm{dl}$ for all soil samples).

fact, E. andevalensis was identified more recently in Portugal than in Spain and, at our knowledge, in the Portuguese IPB E. andevalensis grows exclusively in the São Domingos mining area (river bank of AMD).

The total concentration of trace elements in the soil samples (Table 3 ) is high and within the same range as that given for contaminated soils from the Spanish Pyrite Belt studied by Buján et al. (2006) but higher than those referred by Garcia (2006), both for E. andevalensis soils. The AB-DTAP extractable fraction (Table 2) of all trace elements was higher in the contaminated than in the non-contaminated soils,

Table 3

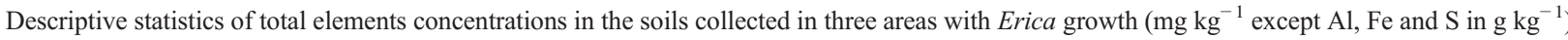

\begin{tabular}{|c|c|c|c|c|c|c|c|c|c|c|}
\hline Statistics & As & $\mathrm{Al}$ & $\mathrm{Cu}$ & $\mathrm{Fe}$ & $\mathrm{Mn}$ & $\mathrm{Pb}$ & $\mathrm{S}$ & $\mathrm{Sb}$ & $\mathrm{Zn}$ & $\mathrm{Hg}$ \\
\hline \multicolumn{11}{|c|}{ E.australis - non contaminated soil $(n=4)$} \\
\hline Mean & 15.03 & 40.36 & 21.49 & 24.63 & 280.6 & 23.71 & 0.20 & 3.30 & 26.41 & $<\mathrm{dl}$ \\
\hline Min. & 12.60 & 31.52 & 15.14 & 19.80 & 64.8 & 18.41 & 0.12 & 1.50 & 19.50 & $<\mathrm{dl}$ \\
\hline Max. & 18.90 & 48.15 & 31.47 & 29.00 & 853.7 & 26.76 & 0.23 & 8.20 & 38.62 & $<\mathrm{dl}$ \\
\hline Median & 14.30 & 40.89 & 19.66 & 24.85 & 102.0 & 24.83 & 0.20 & 1.75 & 23.75 & $<\mathrm{dl}$ \\
\hline Stand. Dev. & 2.74 & 7.45 & 6.99 & 3.90 & 383.5 & 3.81 & 0.08 & 3.27 & 8.44 & - \\
\hline \multicolumn{11}{|c|}{ E. australis - contaminated soil $(n=8)$} \\
\hline Mean & 2123.8 & 44.88 & 266.8 & 91.49 & 120.7 & 5108.7 & 7.60 & 437.9 & 99.40 & 5.3 \\
\hline Min. & 175.0 & 22.65 & 25.2 & 18.30 & 18.65 & 255.6 & 2.67 & 19.2 & 36.41 & $<\mathrm{dl}$ \\
\hline Max. & 11600.0 & 68.70 & 988.8 & 313.0 & 255.0 & 24930.0 & 20.99 & 2150.0 & 215.56 & 17.0 \\
\hline Median & 759.5 & 45.41 & 193.3 & 62.75 & 109.3 & 2429.7 & 6.96 & 199.0 & 85.35 & 3.0 \\
\hline Stand. Dev. & 3864.9 & 16.36 & 312.1 & 95.00 & 82.13 & 8240.9 & 5.85 & 707.4 & 63.71 & 6.0 \\
\hline \multicolumn{11}{|c|}{ E.andevalensis - contaminated soil $(n=12)$} \\
\hline Mean & 1590.1 & 58.55 & 228.5 & 79.91 & 262.7 & 2318.0 & 10.59 & 237.0 & 245.9 & 6.5 \\
\hline Min. & 332.0 & 41.20 & 28.0 & 40.10 & 47.9 & 217.8 & 2.12 & 67.6 & 37.2 & $<\mathrm{dl}$ \\
\hline Max. & 3640.0 & 74.28 & 646.4 & 207.00 & 655.2 & 7168.7 & 25.31 & 550.0 & 1368.7 & 32.0 \\
\hline Median & 1580.0 & 57.54 & 214.7 & 71.45 & 186.6 & 1505.6 & 10.12 & 179.0 & 109.4 & 5.0 \\
\hline Stand. Dev. & 1001.4 & 13.34 & 166.9 & 43.33 & 173.4 & 2128.7 & 6.85 & 160.6 & 371.0 & 8.6 \\
\hline MAV & $12^{* *}$ & - & $50 *$ & - & - & $50^{*}$ & - & $20 * *$ & $150^{*}$ & $1^{*}$ \\
\hline
\end{tabular}

MAV: maximum allowed values for soils with $\mathrm{pH} \leq 5(*)$ according to the Portuguese legislation (Portaria 176/96) or CCME (1997) $\left({ }^{* *}\right)$. 
Table 4

Descriptive statistics of trace elements concentrations ( $\mathrm{mg} \mathrm{kg}^{-1}$, except for $\mathrm{Hg}_{\text {in }} \mu \mathrm{g} \mathrm{kg}^{-1}$ ) in the aerial tissues of the plants (dry weight) collected in the same areas of the soils

\begin{tabular}{|c|c|c|c|c|c|c|c|c|c|}
\hline Statistics & $\mathrm{Al}$ & $\mathrm{Mn}$ & $\mathrm{Cu}$ & $\mathrm{Fe}$ & $\mathrm{Zn}$ & As & $\mathrm{Sb}$ & $\mathrm{Pb}$ & $\mathrm{Hg}$ \\
\hline \multicolumn{10}{|c|}{ E.australis - non contaminated soil $(n=4)$} \\
\hline Mean & 331.3 & 304.0 & 4.36 & 234.6 & 12.28 & 0.77 & 0.022 & 0.92 & 0.49 \\
\hline Min. & 294.8 & 203.6 & 3.48 & 210.6 & 10.15 & 0.57 & 0.010 & 0.62 & 0.36 \\
\hline Max. & 382.3 & 460.3 & 5.12 & 260.2 & 13.63 & 0.99 & 0.040 & 1.15 & 0.59 \\
\hline Median & 324.1 & 276.1 & 4.43 & 233.7 & 12.68 & 0.76 & 0.018 & 0.96 & 0.50 \\
\hline Stand. Dev. & 37.07 & 111.8 & 0.76 & 21.11 & 1.54 & 0.17 & 0.014 & 0.22 & 0.10 \\
\hline \multicolumn{10}{|c|}{ E. australis - contaminated soil $(n=8)$} \\
\hline Mean & 346.3 & 264.8 & 6.66 & 381.1 & 26.01 & 4.94 & 0.077 & 13.58 & 4.37 \\
\hline Min. & 181.7 & 82.40 & 3.01 & 206.9 & 9.93 & 1.58 & 0.028 & 2.40 & 1.27 \\
\hline Max. & 494.2 & 455.8 & 12.77 & 679.8 & 64.41 & 12.47 & 0.177 & 59.13 & 14.20 \\
\hline Median & 314.8 & 259.6 & 5,70 & 380.7 & 18.41 & 3,56 & 0.061 & 8.04 & 2.90 \\
\hline Stand. Dev. & 115.5 & 133.2 & 3.59 & 150.0 & 17.41 & 4.11 & 0.051 & 18.89 & 4.17 \\
\hline \multicolumn{10}{|c|}{ E. andevalensis - contaminated soil $(n=12)$} \\
\hline Mean & 535.8 & 597.1 & 10.42 & 1281.6 & 23.97 & 13.13 & 0.279 & 35.13 & 13.15 \\
\hline Min. & 182.2 & 256.6 & 4.05 & 268.5 & 11.23 & 3.01 & 0.053 & 3.05 & 2.81 \\
\hline Max. & 2314.2 & 1129.7 & 38.30 & 5639.2 & 43.45 & 42.99 & 1.027 & 262.81 & 44.39 \\
\hline Median & 425.4 & 591.3 & 8.11 & 708.3 & 23.28 & 7.75 & 0.18 & 10.88 & 7.00 \\
\hline Stand. Dev. & 573.5 & 271.1 & 9.25 & 1538.3 & 9.75 & 11.89 & 0.276 & 72.62 & 12.16 \\
\hline \multicolumn{10}{|c|}{ Mature leaves tissues for plants in general ${ }^{\mathrm{a}}$} \\
\hline Normal & $50-200^{\mathrm{b}}$ & $30-300$ & $5-30$ & - & $27-150$ & $1-1.7$ & $7-50$ & $5-10$ & - \\
\hline Toxic & - & $400-1000$ & $20-100$ & - & $100-400$ & $5-20$ & 150 & $30-300$ & $0.001-0.003$ \\
\hline
\end{tabular}

a Kabata Pendias and Pendias (2001).

b Srivastava and Gupta (1996).

mainly for $\mathrm{As}, \mathrm{Pb}$ and $\mathrm{Cu}$, which may be due to low soil $\mathrm{pH}, \mathrm{AMD}$ or soil mineralogy.

Mercury, in contaminated soils, presented concentration values from $32 \mathrm{mg} \mathrm{kg}^{-1}$ to values lower than the detection limit $\left(1 \mathrm{mg} \mathrm{kg}^{-1}\right)$, being the majority above $3 \mathrm{mg} \mathrm{kg}^{-1}$ (Table 2). These concentrations exceeded the maximum allowed value for soils according to the Portuguese legislation (1.0 $\mathrm{mg} \mathrm{kg}^{-1}$, Portaria 176/96); however, the available fraction for this element was below the detection limit. In both Erica species, the $\mathrm{Hg}$ concentration was also very low $\left(<0.04 \mathrm{mg} \mathrm{kg}^{-1}\right.$ dry weight; Table 4).

Comparing the contaminated soils where E. andevalensis or E. australis grow, $\mathrm{Al}, \mathrm{S}, \mathrm{Mn}$ and $\mathrm{Zn}$ total concentrations are greater for $E$. andevalensis soils, while $\mathrm{Cu}, \mathrm{Hg}, \mathrm{Pb}, \mathrm{Sb}$ and $\mathrm{As}$ were within the same magnitude in both soils (Table 3). However, the available fraction of $\mathrm{Zn}, \mathrm{Pb}$, As and $\mathrm{Sb}$ reached highest levels in the E. andevalensis soils (Table 2).

The chemical analysis of the aerial parts of both Erica species growing at São Domingos and Moreanes are presented in Table 4. Concentrations of elements in the E. australis aerial tissues were below the toxicity levels referred by Kabata Pendias and Pendias (2001) for most studied elements. However, some plant samples presented $\mathrm{Mn}, \mathrm{Pb}$ and As within the excessive or toxic limits (Table 4). Concentrations of most trace elements in the $E$. andevalensis species were also below the toxicity levels, except for As, Mn $(75 \%$ of the samples) and $\mathrm{Pb}$ (three samples) which were above the toxic limit for plants. Also, Al concentration (for $92 \%$ of both Erica samples) was higher than the maximum value considered normal for plants in general $(200 \mathrm{mg}$ $\mathrm{kg}^{-1}$; Srivastava and Gupta, 1996).

Erica species growing in the São Domingos mining site showed similar $\mathrm{Cu}, \mathrm{Al}$ and $\mathrm{Zn}$ concentrations, but $\mathrm{Fe}, \mathrm{As}, \mathrm{Sb}, \mathrm{Pb}$ and $\mathrm{Hg}$ were higher in $E$. andevalensis (Table 4), which may be due to its soils location near the AMD. The Mn content in E. andevalensis was higher than in E. australis in contaminated soils, presenting E. australis similar amounts of $\mathrm{Mn}$ when growing either in contaminated or non-contaminated soils (Table 4; Fig. 3). Both species are Mn accumulators as demonstrated by the soil-plant transfer coefficient (TC) $>1$, for most of the samples (only three plant samples showed TC between 0.43 and 0.59 ) (Table 5). This capacity for $\mathrm{Mn}$ accumulation was also reported for $E$. andevalensis by Soldevilla et al. (1992) and Buján et al. (2006). As expected, the lowest values of most trace elements were found in E. australis growing in the non-contaminated site (Table 4).

Both Erica species, even in the non-contaminated soils, were able to transport relatively high amounts of Al when compared with most other plants (Table 4), 
indicating a plant tolerance to this element, which according to Kabata Pendias and Pendias (2001) is not necessarily associated with $\mathrm{Al}$ retention in roots. In fact, the bioconcentraction factor (BC) for $\mathrm{Al}$ ranged from 2.38 to 277.65 , whereas the calculated Al soil-plant transfer coefficient (CT) was $<0.03$ (Table 5). The bioconcentraction coefficient reflects more accurately the capacity of the element to be assimilated by plant than the soil-plant transfer coefficient, as only a fraction of the element total soil content is readily available to be uptake. Therefore, to assess plant tolerance to trace elements the soil available fraction rather than soil total trace elements concentration must be considered. Consequently, based on the calculated BC, both Erica species can be considered as Al tolerant plants. The Al tolerance can be a valuable characteristic of these plants as potential colonizing species for high acidic soils, as sulphide mining soils, where $\mathrm{Al}$ in cationic forms is readily available associated with trace elements and low nutrients content. Although for a great number of plant species these conditions induce Al toxicity markedly depressing plant growth, this behaviour was not observed in the studied Erica species.

Concerning As, a severe contaminant in São Domingos mining area, the high levels in the aerial parts of the plants (Table 4) may indicate, as for Al, tolerance for this element $(65 \%$ of the samples with $\mathrm{BC}$ ranging from 2.26 to 43; Table 5). In most plants, As is passively absorbed staying in the roots (Srivastava and Gupta, 1996). This effect was confirmed by Buján et al. (2006) for E. andevalensis. However, in this study, plant roots were not analysed, but the aerial part of the plants contained between 3 and $43 \mathrm{mg} \mathrm{As} \mathrm{kg}{ }^{-1}$ (Table 4), which are above the normal range for plants $(1-1.7 \mathrm{mg}$ $\mathrm{kg}^{-1}$ ), according to Kabata Pendias and Pendias (2001). Although $E$. andevalensis presented higher concentrations of As than E. australis, the relationship between As extractable by AB-DTPA (soil bioavailable fraction) and As concentration in the plant follows a similar pattern, that is, the bioavailable fraction concentration increase corresponds to a plant concentration increase (Fig. 3).

Despite the generally high total and available $\mathrm{Pb}$ concentrations in soils (Tables 2 and 3 ), this element was not highly transported to the aerial parts of the plants (BC $<1$ in $70 \%$ of the plants in contaminated soils and TC ranging between 0.002 and 0.224 ; Table 5), which may suggest that $\mathrm{Pb}$ is retained in the roots. These results seem to be consistent with those obtained in Spain for E. andevalensis: $437 \mathrm{mg} \mathrm{Pb} \mathrm{kg}^{-1}$ in roots (Buján et al., 2006) and 2.8-21 mg Pb kg${ }^{-1}$ in shoots (Garcia, 2006). Although the $\mathrm{Pb}$ amounts was higher than $10 \mathrm{mg} \mathrm{kg}^{-1}$ (maximum normal value for most other plants, Table 4) in some Erica plants on the contaminated soils (six samples of E. andevalensis and two samples of E. australis, in the range of $13-263 \mathrm{mg}$ $\mathrm{kg}^{-1}$ ), the transport to shoots seems to be independent of $\mathrm{Pb}$ available fraction in the soils (Fig. 3).

Despite $\mathrm{Cu}$ was the main exploited element in São Domingos, the mean concentration of this element in soils where E. andevalensis and E. australis grow (mean of total and available fraction, 229-267 and 39$34 \mathrm{mg} \mathrm{kg}^{-1}$; respectively; Tables 2 and 3) was lower than those reported by Asensi et al. (1999) (mean of soil total $\mathrm{Cu}-942 \mathrm{mg} \mathrm{kg}^{-1}$ ), similar to those found by Soldevilla et al. (1992) (mean of total and available fraction, respectively 205 and $36 \mathrm{mg} \mathrm{kg}^{-1}$ ) and higher than those presented by Garcia (2006) (mean of soil total $\mathrm{Cu}-66 \mathrm{mg} \mathrm{kg}^{-1}$ ) concerning soils from the Spanish Pyrite Belt where copper was also exploited. These differences are related to the irregular $\mathrm{Cu}$ recovery by the metallurgical processes in different mines of the IPB.

Copper concentrations observed for E. andevalensis plants at São Domingos are of the same order of magnitude of the results reported in literature. The estimated bioaccumulation coefficient lies between 0.072 and 0.861 for 11 samples (Table 5), which is in disagreement with Asensi et al. (1999) conclusion. The studies carried out by Asensi et al. (1999) on $E$. andevalensis, growing in a pot experience using a mixture of commercial potting substrate and $\mathrm{Cu}$ ore, concluded by its high $\mathrm{Cu}$-tolerance, despite similar copper concentrations found in the plant. However, the relationship between $\mathrm{Cu}$ available fraction in the São Domingos soils and E. andevalensis $\mathrm{Cu}$ concentrations (Fig. 3) follows the same pattern of that obtained by Asensi et al. (1999). Increasing levels of soil bioavailable $\mathrm{Cu}$ did not correspond to high $\mathrm{Cu}$ concentration in the plant. A similar behaviour was also observed for E. australis (Fig. 3). The TC $<1$ (Table 5) for both $E r-$ ica species shows that are not $\mathrm{Cu}$-accumulators, which is in opposition with Soldevilla et al. (1992) conclusions.

Iron concentration was relatively high in E. andevalensis (269-5639 $\mathrm{mg} \mathrm{kg}^{-1}$ ) (Table 4) when compared with the amounts (185 and 409-744 $\mathrm{mg} \mathrm{kg}^{-1}$ ) reported by Soldevilla et al. (1992) and Garcia (2006), respectively, reflecting the soil $\mathrm{Fe}$ available fraction enrichment (Table 2) by the AMD, although no visual morphological symptoms of Fe toxicity disorders were observed. The BC factors estimated for both Erica species (Table 5) may suggest a Fe-tolerance.

Zinc concentration in Erica plants was, in general, below the normal range for most plants (Table 4) and even, in some samples, within the deficiency range (10- 
$20 \mathrm{mg} \mathrm{kg}^{-1}$; Kabata Pendias and Pendias, 2001), despite the concentrations of bioavailable $\mathrm{Zn}$ fraction (percentage from total soil concentration ranging between 1.1 and 63.1 , median $=9.3 \%$ ). The low $\mathrm{Zn}$ concentration in Erica plant tissues could not imply deficiency as no visual morphological symptoms of Zn deficiency were
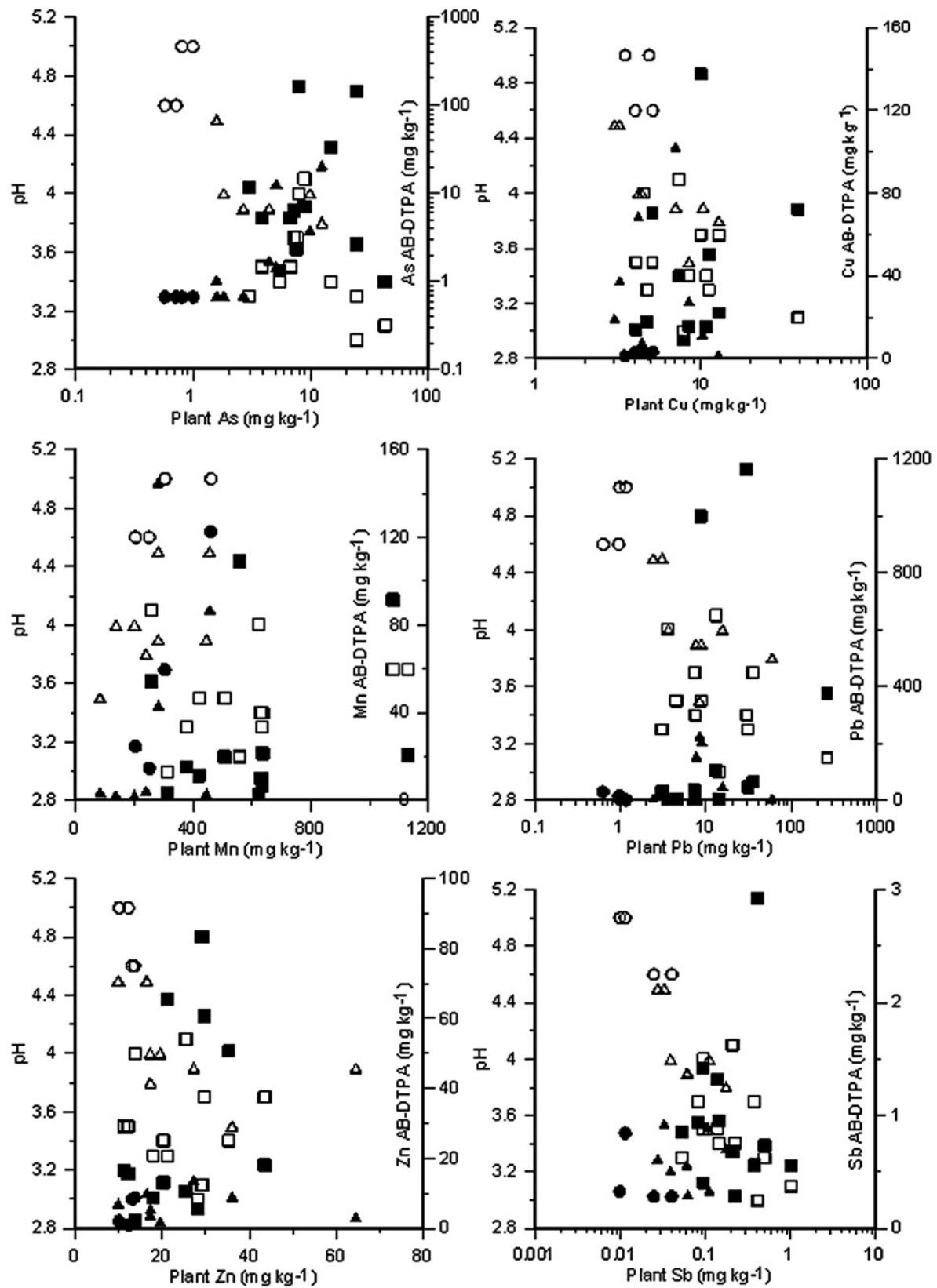

\begin{tabular}{|ll|}
\hline$\square$ & E and (pH) \\
$\Delta$ & $\mathrm{E}$ and (avail_soil)) \\
$\Delta$ & $\mathrm{Ea}(\mathrm{pH})$ \\
$\mathbf{0}$ & $\mathrm{Ea}$ (avail_soil) \\
$\mathbf{0}$ & $\mathrm{NCE}$ Ea (pH) \\
& $\mathrm{NCE}$ Ea (avail_soil)
\end{tabular}

Fig. 3. Scatter plot diagrams representing the relation between $\mathrm{As}, \mathrm{Cu}, \mathrm{Mn}, \mathrm{Pb}, \mathrm{Zn}$ and Sb concentrations in Erica australis and Erica andevalensis $\left(\mathrm{mg} \mathrm{kg}^{-1}\right)$ and $\mathrm{pH}$ and AB-DTPA extractable fraction in soils ( $\mathrm{mg} \mathrm{kg}^{-1}$ ) where these plants grow. 
Table 5

Soil-plant transfer coefficients - TC ([plant]/[total soil]) and bioconcentration coefficients - BC ([plant]/ [bioavailable soil fraction, extracted by AB-DTPA]) for E. australis growing in non-contaminated soils (NCEa), E. australis growing in contaminated soils (Ea) and E. andevalensis growing in contaminated soils (Eand), of $\mathrm{Al}, \mathrm{As}, \mathrm{Cu}, \mathrm{Mn}, \mathrm{Fe}, \mathrm{Pb}, \mathrm{Sb}$ and $\mathrm{Zn}$

\begin{tabular}{|c|c|c|c|c|c|c|c|c|c|c|c|c|c|c|c|c|}
\hline \multirow[t]{2}{*}{ Sample } & \multicolumn{2}{|l|}{$\mathrm{Al}$} & \multicolumn{2}{|l|}{ As } & \multicolumn{2}{|l|}{$\mathrm{Cu}$} & \multicolumn{2}{|l|}{$\mathrm{Mn}$} & \multicolumn{2}{|l|}{$\mathrm{Fe}$} & \multicolumn{2}{|l|}{$\mathrm{Pb}$} & \multicolumn{2}{|l|}{$\mathrm{Sb}$} & \multicolumn{2}{|l|}{$\mathrm{Zn}$} \\
\hline & $\mathrm{TC}$ & $\mathrm{BC}$ & $\mathrm{TC}$ & $\mathrm{BC}$ & $\mathrm{TC}$ & $\mathrm{BC}$ & $\mathrm{TC}$ & $\mathrm{BC}$ & $\mathrm{TC}$ & $\mathrm{BC}$ & $\mathrm{TC}$ & $\mathrm{BC}$ & $\mathrm{TC}$ & $\mathrm{BC}$ & $\mathrm{TC}$ & $\mathrm{BC}$ \\
\hline NCEa6 & 0.007 & 6.61 & 0.039 & - & 0.338 & - & 3.14 & 8.25 & 0.010 & 0.533 & 0.036 & 0.114 & 0.005 & - & 0.583 & 1.58 \\
\hline NCEa7 & 0.007 & 47.63 & 0.043 & - & 0.110 & - & 0.54 & 3.75 & 0.007 & 1.99 & 0.043 & 0.576 & 0.006 & - & 0.263 & 5.07 \\
\hline NCEa8 & 0.009 & 3.40 & 0.052 & - & 0.203 & - & 3.76 & 17.02 & 0.011 & 0.48 & 0.027 & 0.072 & 0.016 & - & 0.547 & 1.57 \\
\hline NCaE9 & 0.010 & 9.56 & 0.079 & - & 0.248 & - & 2.20 & 5.07 & 0.011 & 1.35 & 0.053 & 0.972 & 0.007 & - & 0.625 & 12.20 \\
\hline Ea5 & 0.003 & 6.06 & 0.009 & 0.624 & 0.507 & 9.58 & 5.10 & 65.24 & 0.009 & 1.95 & 0.224 & 25.34 & 0.002 & 0.254 & 0.415 & 3.46 \\
\hline Ea14 & 0.004 & 6.33 & 0.003 & 0.414 & 0.029 & 0.313 & 0.43 & 24.72 & 0.008 & 1.13 & 0.002 & 0.038 & $<0.001$ & 0.121 & 0.276 & 4.16 \\
\hline Ea18 & 0.008 & 3.81 & 0.008 & 8.00 & 0.094 & 0.935 & 1.74 & 190.54 & 0.005 & 3.97 & 0.009 & 0.044 & 0.001 & 0.218 & 0.855 & 24.15 \\
\hline Ea19 & 0.020 & 5.70 & 0.001 & 2.69 & 0.015 & 0.599 & 3.11 & 119.47 & 0.001 & 2.41 & 0.001 & 0.353 & $<0.001$ & 0.343 & 0.433 & 14.63 \\
\hline Ea20 & 0.007 & 24.24 & 0.003 & 1.58 & 0.012 & 0.087 & 2.67 & 5.28 & 0.005 & 2.42 & 0.003 & 0.246 & $<0.001$ & 0.036 & 0.076 & 1.70 \\
\hline $\mathrm{Ea} 21$ & 0.013 & 55.59 & 0.004 & 2.66 & 0.007 & 0.069 & 1.96 & 6.59 & 0.004 & 1.37 & 0.002 & 0.051 & $<0.001$ & 0.110 & 0.286 & 2.04 \\
\hline $\mathrm{Ea} 22$ & 0.006 & 27.80 & 0.009 & 4.74 & 0.032 & 0.161 & 3.71 & 1.94 & 0.006 & 1.55 & 0.009 & 0.801 & 0.001 & 0.046 & 0.064 & 1.49 \\
\hline Ea23 & 0.014 & 2.42 & 0.005 & 5.44 & 0.081 & 0.061 & 7.30 & 68.06 & 0.015 & 4.06 & 0.001 & 2.15 & $<0.001$ & 0.079 & 0.472 & 5.16 \\
\hline Eand1 & 0.010 & 50.94 & 0.009 & 0.169 & 0.031 & 0.861 & 1.61 & 94.12 & 0.013 & 1.02 & 0.004 & 8.58 & $<0.001$ & 0.142 & 0.060 & 5.29 \\
\hline Eand2 & 0.006 & 10.87 & 0.004 & 0.048 & 0.161 & 1.69 & 13.02 & 234.01 & 0.008 & 0.948 & 0.016 & 1.19 & $<0.001$ & 0.067 & 0.372 & 6.92 \\
\hline Eand3 & 0.004 & 2.38 & 0.002 & 0.258 & 0.023 & 0.263 & 3.54 & 100.05 & 0.003 & 0.624 & 0.002 & 0.094 & $<0.001$ & 0.063 & 0.178 & 2.08 \\
\hline Eand4 & 0.010 & 47.27 & 0.008 & 0.452 & 0.063 & 0.541 & 0.964 & 63.18 & 0.026 & 3.54 & 0.009 & 1.26 & $<0.001$ & 0.150 & 0.189 & 1.56 \\
\hline Eand10 & 0.006 & 8.65 & 0.027 & 1.27 & 0.062 & 0.184 & 0.587 & 4.72 & 0.017 & 1.30 & 0.019 & 0.122 & $<0.001$ & 0.306 & 0.222 & 2.38 \\
\hline Eand11 & 0.004 & 2.74 & 0.002 & 1.26 & 0.061 & 0.282 & 4.45 & 37.04 & 0.005 & 0.879 & 0.011 & 2.68 & $<0.001$ & 0.231 & 0.129 & 0.688 \\
\hline Eand12 & 0.009 & 20.34 & 0.012 & 9.20 & 0.050 & 0.222 & 2.21 & 25.06 & 0.025 & 3.07 & 0.011 & 0.667 & $<0.001$ & 0.677 & 0.189 & 0.323 \\
\hline Eand13 & 0.003 & 24.47 & 0.003 & 0.720 & 0.022 & 0.072 & 2.92 & 25.32 & 0.004 & 0.582 & 0.002 & 0.009 & $<0.001$ & 0.104 & 0.118 & 0.775 \\
\hline Eand15 & 0.009 & 248.22 & 0.004 & 4.08 & 0.017 & 0.686 & 2.54 & 29.31 & 0.003 & 6.48 & 0.004 & 0.026 & $<0.001$ & 1.60 & 0.026 & 0.696 \\
\hline Eand16 & 0.006 & 25.57 & 0.013 & 1.14 & 0.036 & 0.072 & 6.16 & 11.83 & 0.015 & 1.15 & 0.012 & 0.198 & $<0.001$ & 0.088 & 0.307 & 0.486 \\
\hline Eand17 & 0.031 & 277.65 & 0.050 & 43.00 & 0.093 & 0.530 & 1.64 & 5.13 & 0.072 & 45.72 & 0.061 & 0.698 & $<0.001$ & 1.84 & 0.128 & 0.350 \\
\hline Eand24 & 0.008 & 24.72 & 0.016 & 3.25 & 0.087 & 0.584 & 2.60 & 54.66 & 0.013 & 6.04 & 0.031 & 0.545 & $<0.001$ & 0.666 & 0.349 & 2.41 \\
\hline
\end{tabular}

observed, which may suggest that Erica species show low $\mathrm{Zn}$ requirement when compared with most plants. Moreover, the deficiency content of $\mathrm{Zn}$ in plants may vary considerably, being related to each genotype and the interaction of $\mathrm{Zn}$ with other elements within the plant tissues (Kabata Pendias and Pendias, 2001). The uptake of this micronutrient, considering the soil available fraction concentrations (AB-DTPA extracted), seems to be efficient, as $\mathrm{BC}>1$ for most of the Erica plants (ranging between 0.35 and 24.2; median of 3.81 for E. australis and 1.16 for E. andevalensis; Table 5). In addition, the transport of $\mathrm{Zn}$ to shoots is independent of $\mathrm{Zn}$ available fraction in the soils (Fig. 3).

In the contaminated soils of São Domingos Sb attained high concentrations (Table 3), exceeding $20 \mathrm{mg} \mathrm{kg}^{-1}$, the maximum allowable value for soils (CCME, 1997). However, the bioavailable $\mathrm{Sb}$ soil fraction concentrations lie between 0.28 and $0.97 \mathrm{mg} \mathrm{kg}^{-1}$ (one E. andevalensis soil sample exception with $2.92 \mathrm{mg} \mathrm{kg}^{-1}$ ), which directly influence the low Sb plant content (Table 4 and Fig. 3).

The relation between soil $\mathrm{pH}$, AB-DTPA extractable fraction of $\mathrm{As}, \mathrm{Cu}, \mathrm{Mn}, \mathrm{Pb}, \mathrm{Sb}$ and $\mathrm{Zn}$, and the same elements in plants (Fig. 3) established a clear difference between contaminated and non-contaminated soils and the respective plants collected in the same sites. At São Domingos, the two Erica species were never found cohabiting in the same areas, a peculiar characteristic of this zone in opposition to the soils of the Spanish IPB (Garcia et al., 2005; Buján et al., 2006). In the São Domingos contaminated soils the relation between the elements concentrations in plants and soil bioavailable fraction is not a unifying criterion to evaluate the difference observed between $E$. andevalensis and E. australis field implantation, as illustrated by $\mathrm{Sb}, \mathrm{As}$, $\mathrm{Pb}$ and $\mathrm{Cu}$ irregular distribution (Fig. 3). Soil $\mathrm{pH}$ is then the characteristic which divides the growth areas of both Erica species, as E. australis was found in soils with $\mathrm{pH}$ ranging between 3.5 and 4.5 while $E$. andevalensis grows in soils with pH between 3 and 4 (Fig. 3).

Considering the size of São Domingos area $\left(30 \mathrm{~km}^{2}\right)$ affected by the old mining processes, the use of high cost remediation technologies is not realistic. Therefore, the phytostabilisation technique, by using specific tolerant plants with or without the application of soil amendments, could be a promising strategy for this abandoned mining area. The objective of phytostabilisation, a non-expensive and non-disruptive technique to the landscape, is not to remove contaminant elements from a site but rather to 
stabilise them and reduce the risk to human health and the environment (Wong, 2003; Rittmann, 2004; Adriano et al., 2004; Clemente et al., 2006), hence the importance of appropriate vegetation. The acidic soils of São Domingos $(\mathrm{pH} \leq 4.5)$, highly contaminated by trace elements, began to be colonized by some plants species that seem to be adapted to such extreme environmental conditions. This is the case of E. andevalensis and E. australis plants according to the results discussed above. As both species are $\mathrm{Mn}$-accumulators and tolerants to low $\mathrm{pH}$ and high $\mathrm{Al}, \mathrm{Pb}$ and As concentrations, chemical stabilisation of soils and waste materials of mining sulphide areas can be achieved. Erica species can also contribute to increase weathering and pedogenic processes of the waste materials and river bank sediments improving its physical and chemical characteristics by organic matter addition as a result of plant development. This will increase the substratum fertility making possible its colonisation by other plant species more nutrient exigent.

In addition, E. andevalensis by growing in the river banks may partially decrease the negative impact of current velocity and high water discharge in spring and winter periods, decreasing river bank erosion. E. australis, which colonise mainly waste dump materials of gossanous nature, may contribute to mitigate wind and water erosion of these hazardous materials. Moreover, E. andevalensis, an endemic plant restricted to the Iberian Pyrite Belt, is classified as endangered species growing in extreme ecological conditions as the sulphide mining environments, so its habitat preservation is essential in conservation of this species. These two ornamental species can then attenuate the visual impact of degraded mining areas promoting and preserving the mining patrimony.

\section{Conclusions}

The different types of waste materials deposited in the São Domingos mining area has high acid generating potential, as it can release enormous quantities of $\mathrm{Al}, \mathrm{Fe}$, $\mathrm{SO}_{4}^{2-}$ and in some extend $\mathrm{Pb}$ and $\mathrm{Cu}$, which contaminate the river bank soils and stream system. Also, seepage water showed high redox potential, high conductivity and low $\mathrm{pH}$ values, being classified as oxidised water (mining water).

Soils in the mining area, especially those located in the vicinity of waste materials and acid mine drainage, are highly contaminated in trace elements, mainly $\mathrm{Pb}$, $\mathrm{As}, \mathrm{Sb}$, and to some extent $\mathrm{Cu}$ and $\mathrm{Zn}$. Soil bioavailable fraction (AB-DTPA extracted) for most of the elements showed relatively high values when compared with the soil total concentration.
E. andevalensis and E. australis do not cohabit in the same area at São Domingos; on the contrary, their habitats are clearly distinct in this zone. Unlike the Andévalo region, at São Domingos E. andevalensis was not found outside the river bank areas periodically flooded. The most interesting feature of $E$. andevalensis is the ability to grow in very hostile conditions for life, such as soils with $\mathrm{pH}$ values between 3 and 4 and high contents of toxic elements such as $\mathrm{Al}, \mathrm{Pb}, \mathrm{Fe}$, As and $\mathrm{Sb}$. Also, E. australis grows in highly contaminated soils but, in this study, was not found in soils with $\mathrm{pH}$ values below 3.5.

Most of trace elements concentrations in E. andevalensis and E. australis growing in the contaminated soils ranged the normal levels, however some plant samples presented $\mathrm{Mn}, \mathrm{Pb}$ and As within the excessive or toxic limits for plants. Both Erica species, even in the noncontaminated soils are Al-tolerant and Mn-accumulators. In contaminated soils these species are also Astolerant.

For all the exposed reasons, E. andevalensis and E. australis may be considered of great importance for the recovery of the sulphide mining areas in regions with climate conditions compatible with breeding and growing of these plant species.

\section{References}

Adriano, D.C., Wenzel, W.W., Vangronsveld, J., Bolan, N.S., 2004. Role of the assisted natural remediation in environmental cleanup. Geoderma 122, 121-142.

Anawar, M.H., Garcia-Sanchez, A., Murciego, A., Buyolo, T., 2006. Exposure and bioavailability of arsenic in contaminated soils from the La Parrilla mine, Spain. Environmental Geology 50, 170-179.

Aparício, A., García-Martin, F., 1996. The reproductive biology and breeding system o Erica andevalensis Cabezudo and Rivera (Ericaceae), an endangered edaphic endemic of southwestern Spain. Implications for its conservation. Flora 191, 345-351.

Asensi, A., Bennett, F., Brooks, R., Robinson, B., Stewart, R., 1999. Cooper uptake studies on Erica andevalensis, a metal-tolerant plant from southwestern Spain. Communications in Soil Science and Plant Analysis 30 (11-12), 1615-1624.

Buján, E., Saiz, J.L., Ceacero, C.J., Macias, F., 2006. Relaciones sueloplanta en comunidades de E. andevalensis en suelo de mina de la Faja Pirítica Andaluza. Resúmenes, II Congresso Iberico de la Ciencia del Suelo. 1 pp. Huelva, Spain.

Cabezudo, B., Rivera, J., 1980. Notas taxonómicas y corológicas sobre la Flora de Andalucía Occidental. 2: Erica andevalensis Cabezudo \& Rivera sp. nov. Lagascalia, 9 (2), pp. 223-226.

Capelo, J., Bingre, P., Arsénio, P., Espírito Santo, M.D., 1998. Uma ericácea nova para a flora portuguesa. Silva Lusitana, 6 (1), p. 119. Lisboa, Portugal.

CCME - Canada Council of Ministers of the Environment, 1997. Canadian Environmental Quality Guidelines for the protection of environmental and human healthWinnipeg.

Clemente, R., Almela, C., Bernal, M.P., 2006. A remediation strategy based on active phytoremediation followed by natural attenuation in a soil contaminated by pyrite waste. Environmental Pollution 143, 397-406. 
Custódio, J. 1996. Sistemas de lavra na Mina de S. Domingos. In: Câmara Municipal de Castro Verde (Ed.), Mineração no Baixo Alentejo. Castro Verde, Portugal 174-185.

Freitas, H., Prasad, M.N.V., Pratas, J., 2004. Plant community tolerant to trace elements growing on the degraded soils of São Domingos mine in the south east of Portugal: environmental implications. Environment International 30, 65-72.

Garcia, B.M., 2006. Análisis del estrés oxidativo en Ericáceas de la comarca de El Andévalo (Huelva). PhD Thesis. Universidad de Huelva, Spain. http://www.uhu.es/francisco.cordoba/investigacion/proyectos/pdf/Tesina-B.pdf.

Garcia, B.M., Hidalgo, P.J., Dominguez, D.M., Heras, M.A., Garcia, F.C., 2005. Por qué Erica andevalensis sobrevive en condiciones extremas de contaminación ambiental? Abstracts of the 6th Iberian and 3rd Iberoamerican Congress of Environmental Contamination and Toxicology, p. 260. Cadiz, Spain.

Garrels, R.M., Christ, C.L., 1965. Solutions, Minerals and Equilibria. Harper and Row, New York. 450 pp.

Gaspar, O.C., 1998. História da mineração dos depósitos de sulfuretos maciços vulcanogénicos da Faixa Piritosa Portuguesa. Boletim de Minas 35/4, 401-414

Hanlon, E.A., Johnson, G.V., Jones, J.B., Kalra, Y. Miller, R.O., Soltanpour, P.N., Tucker, M.R., Warnke, D.D., Watson, M., 1999. Soil analysis. Handbook of reference methods. Soils and Plant Analysis Council, Inc. CRC Press, Boca Raton, London, 247 pp.

Kabata Pendias, A., Pendias, H., 2001. Trace Elements in Soils and Plants, 3rd ed. CRC Press, Boca Raton, FL. 413 pp.

Leistel, J.M., Marcoux, E., Thiéblemont, D., Quesada, C., Sanchez, A., Almodóvar, G.R., Pascual, E., Sáez, R., 1998. The volcanic-hosted massive sulphide deposits of the Iberian Pyrite Belt. Mineral Deposita, vol. 33. Springer-Verlang, pp. 2-30.

Martins, L., Oliveira, D., 2000. Exploration and Mining. Instituto Geológico e Mineiro, Lisboa. 20 pp.

Mehra, O.P., Jackson, M.L., 1960. Iron oxides removal from soils and clays by a dithionite-citrate-bicarbonate system buffered with sodium bicarbonate. Clays and Clay Minerals - Proceedings of the 7th National Conference on Clays and Clay Minerals, vol. 7, pp. 317-327.

Nagaraju, A., Karimulla, S., 2002. Accumulation of elements in plants and soils in an around Nellore mica belt, Andhra Pradesh, India a biogeochemical study. Environmental Geology 41, 852-860.
Oliveira, J.T., Silva, J.B., 1990. Carta Geológica de Mértola Fl. 46D na escala 1/50000 e respectiva Notícia Explicativa, Serviços Geológicos de Portugal.

Portaria 176/96. 3 de Outubro de 1996 (II Série). Transposal of Directive n ${ }^{\circ}$ 86/278 CEE. Ministério da Agricultura, do Desenvolvimento e das Pescas e do Ambiente.

Prasad, M.N., Freitas, M.H., 2003. Metal hyperaccumulation in plants - biodiversity prospecting for phytoremediation technology. Electronic Journal of Biotechnology 6 (3), 285-321.

Quental, L., Bourguignon, A., Sousa, A.J., Batista, M.J., Brito, M.G., Tavares, T., Abreu, M.M., Vairinho, M., Cottard, F., 2002. MINEO Southern Europe environment test site. Contamination impact mapping and modelling — Final Report. IST-1999-10337. http:// www.brgm.fr/mineo.

Rittmann, E.B., 2004. Definition, objectives and evaluation of natural attenuation. Biodegradation 15, 349-357.

Rivas-Martínez, S., De la Fuente, V., Rodríguez, N., Ortúñez, E., Amils, R., 2001. Mineral composition of the soils and Erica andevalensis plants community in the Tinto river (Southwest Spain). XVIII Jornadas de Fitosociología. Libro de Resumenes, p. 163.

Soldevilla, M., Maranón, T., Cabrera, F., 1992. Heavy metal content in soil and plants from a pyrite mining area in southweast Spain. Communications in Soil Science and Plant Analysis 23 (11 and 12), 1301-1319.

Srivastava, P.C., Gupta, U.C., 1996. Trace Elements in Crop Production. Science Publishers, Inc., USA. 356 pp.

Veigas, M.I.C., 2005. Flora e vegetação da Mina de São Domingos (Mértola). Trabalho Final de Curso. Universidade de Évora, Portugal. 142 pp.

Walkley, A., Black, I.A., 1934. An examination of Degtjareff method for determining soil organic matter and a proposed modification of the chromic acid titration method. Soil Science 37, 29-38.

Webb, J., 1958. Observations on the geology and origin of the S. Domingos Pyrite deposits, Portugal. Comunicações Serviços Geológicos de Portugal, Lisboa T. 42, 129-143.

Wong, M.H., 2003. Ecological restoration of mine degraded soils, with emphasis on metal contaminated soils. Chemosphere 50, 775-780. 